\title{
CO Disrupts the Reduced H-Cluster of FeFe Hydrogenase. A Combined DFT and Protein Film Voltammetry Study
}

\author{
Carole Baffert, ${ }^{\dagger}$ Luca Bertini, ${ }^{\neq}$Thomas Lautier, $^{\S}$ Claudio Greco, ${ }^{\ddagger}$ Kateryna Sybirna, ${ }^{\perp}$ Pierre Ezanno, ${ }^{+}$ \\ Emilien Etienne, ${ }^{\dagger}$ Philippe Soucaille, ${ }^{\S}$ Patrick Bertrand, ${ }^{\dagger}$ Hervé Bottin, ${ }^{\perp}$ Isabelle Meynial-Salles, ${ }^{\S}$ \\ Luca De Gioia, ${ }^{*, \neq}$ and Christophe Léger, \\ ${ }^{\dagger}$ Bioenergetics and Engineering of Proteins, CNRS, UPR 9036, 31 chemin Joseph Aiguier, 13402 Marseille Cedex 20, France \\ ${ }^{\ddagger}$ Department of Biotechnology and Biosciences, Università degli Studi di Milano-Bicocca, Milan 20126, Italy \\ ${ }^{\S}$ Université de Toulouse, INSA, UPS, INP, LISBP, INRA:UMR792,135 CNRS:UMR 5504, Avenue de Rangueil, 31077 Toulouse, \\ France \\ ${ }^{\perp}$ iBiTec-S, SB2SM, LPB (URA CNRS 2096), DSV, CEA, 91191 Gif-sur-Yvette, France
}

Supporting Information

ABSTRACT: Carbon monoxide is often described as a competitive inhibitor of FeFe hydrogenases, and it is used for probing $\mathrm{H}_{2}$ binding to synthetic or in silico models of the active site $\mathrm{H}$-cluster. Yet it does not always behave as a simple inhibitor. Using an original approach which combines accurate electrochemical measurements and theoretical calculations, we elucidate the mechanism by which, under certain conditions, $\mathrm{CO}$ binding can cause permanent damage to the $\mathrm{H}$-cluster. Like in the case of oxygen inhibition, the reaction with $\mathrm{CO}$ engages the entire $\mathrm{H}$-cluster, rather than only the $\mathrm{Fe}_{2}$ subsite.

$\mathrm{H}$ ydrogenases $\left(\mathrm{H}_{2}\right.$ ases $)$, the enzymes that catalyze the biological production and oxidation of $\mathrm{H}_{2}$, are classified according to the metal content of their active site. In FeFe$\mathrm{H}_{2}$ ases, $\mathrm{H}_{2}$ activation occurs at the $\mathrm{H}$-cluster, which consists of a $\left[\mathrm{Fe}_{2}(\mathrm{CO})_{3}(\mathrm{CN})_{2}(\mu\right.$-dtma $\left.)\right]$ subsite $(\mathrm{dtma}=$ dithiomethylamine $)$ covalently bound to a $[4 \mathrm{Fe} 4 \mathrm{~S}]$ cluster (Scheme 1$)$. During catalysis, the $2 \mathrm{Fe}$ subsite exists in the $\mathrm{Fe}^{\mathrm{II}} \mathrm{Fe}^{\mathrm{I}}$ and $\mathrm{Fe}^{\mathrm{I}} \mathrm{Fe}^{\mathrm{I}}$ states (Hox and Hred, respectively). ${ }^{1}$ The cubane is reduced in the so-called "super-red" state (Hsred). ${ }^{2}$ In theoretical and experimental studies of the $\mathrm{H}$-cluster, $\mathrm{CO}$ is often considered as an innocent ligand which competes for hydrogen, although early experiments with the $\mathrm{H}_{2}$ ase from Clostridium pasteurianum $(\mathrm{Cp})$ showed that $\mathrm{CO}$ may also alter the enzyme in an irreversible manner. ${ }^{3}$ Recent experiments clarified this by demonstrating that $\mathrm{CO}$ inhibition is fully reversible when the enzyme is oxidizing $\mathrm{H}_{2}$, not when it is producing $\mathrm{H}_{2}{ }^{4}$ Here we elucidate the nature of the irreversible damage induced by exogenous $\mathrm{CO}$.

Using protein film voltammetry $(\mathrm{PFV})^{5}$ and methods described before, ${ }^{6,7}$ we have quantitatively examined the kinetics of $\mathrm{CO}$ inhibition of the $\mathrm{FeFe} \mathrm{H}_{2}$ ases from Clostridium acetobutylicum $(\mathrm{Ca})$ and Chlamydomonas reinhardtii $(\mathrm{Cr})$. We found that inhibition proceeds by reversible formation of an inactive enzyme-CO complex, which irreversibly inactivates in a first-order irreversible process in the range of potential that favors the formation of Hred. This behavior is explained by DFT calculations:
Scheme 1. Active Site (H-Cluster) of FeFe Hydrogenase

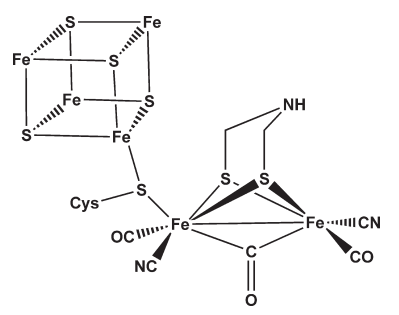

$\mathrm{CO}$ binding to Hred leads to cleavage of the bond between the $\mathrm{Fe}$ and the cysteine $S$ that bridges the $\mathrm{Fe}_{2}$ and [4Fe4S] subsites (Scheme 1). The CO-bound, reduced, disrupted $2 \mathrm{Fe}$ cluster is so stable that this process is irreversible. However, $\mathrm{CO}$ dissociation can occur if the Hred-CO state is taken to very low potential before the $\mathrm{H}$-cluster has fallen apart, because the Hsred-CO species does not rupture and easily releases $\mathrm{CO}$.

The procedures we used to purify the FeFe hydrogenases from $\mathrm{Ca}$ (hydA, Strep-tagged, and homologously expressed) and $\mathrm{Cr}$ (hydA1, Strep-tagged, and heterologously expressed in Shewanella oneidensis) have been described in refs $7 \mathrm{~b}$ (and references therein) and $7 c$, respectively.

Panel A in Figure 1 shows a steady-state voltammogram recorded with $\mathrm{Ca} \mathrm{FeFe}_{2}$ ase adsorbed at a rotating disk graphite electrode (see methods in Supporting Information (SI)). The open circuit potential (OCP) equates the reduction potential of the $\mathrm{H}^{+} / \mathrm{H}_{2}$ couple and marks the limit between oxidative and reductive catalysis $\left(\mathrm{H}_{2}\right.$ oxidation versus production). The vertical arrows indicate the potentials that were used in the chronoamperometric experiments shown in panels $\mathrm{C}-\mathrm{E}$. In each case, the enzyme activity (the current) was monitored as a function of time, in the dark, while aliquots of a solution saturated with $\mathrm{CO}$ were repeatedly injected in the electrochemical cell. The change in $\mathrm{CO}$ concentration against time is shown in panel B. After each injection, $\mathrm{CO}$ is flushed away by the stream of $\mathrm{H}_{2}$, and its concentration decays quickly (typical time constant $\tau=15 \mathrm{~s}$ ),

Received: November 26, 2010

Published: January 27, 2011 


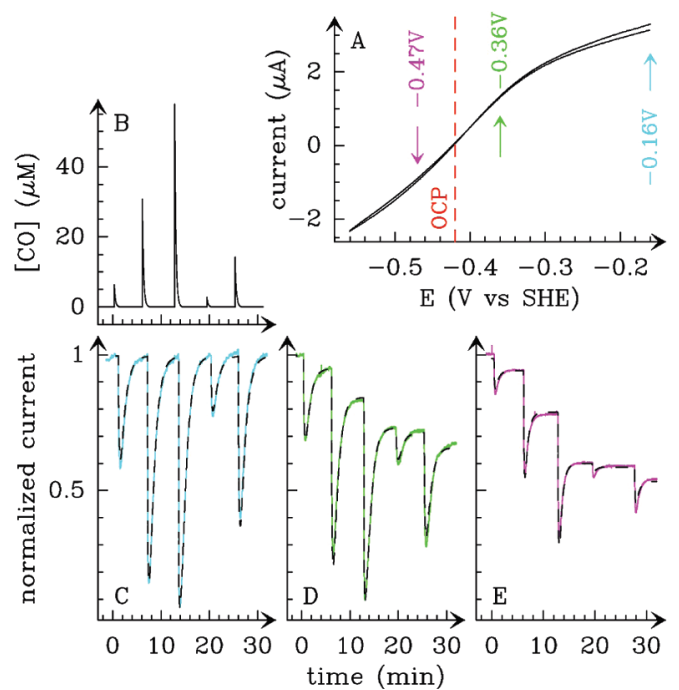

Figure 1. (A) Steady-state voltammogram for $\mathrm{Ca} \mathrm{FeFe} \mathrm{H}_{2}$ ase, 1 atm of $\mathrm{H}_{2}, \mathrm{pH} 7,30^{\circ} \mathrm{C}, 20 \mathrm{mV} / \mathrm{s}, 3000 \mathrm{rpm}$. The open circuit potential (OCP) is indicated by a dashed red line. (B) $\mathrm{CO}$ concentration against time. $(\mathrm{C}-\mathrm{E})$ Normalized current traces showing the activity changes that result from the sequence of injections shown in panel B, recorded at $E=-0.16$ (C), -0.36 (D), and $-0.47 \mathrm{~V}$ (E), in the dark, 1 atm of $\mathrm{H}_{2}, \mathrm{pH} 7,30^{\circ} \mathrm{C}$. See raw data in SI Figure S1. The dashed lines are the best fit to the model shown in Figure 2. ${ }^{6,7}$ In these experiments, the concentration of inhibitor varies, and the activity is a complex function of time (even when $k_{3}=0$, see eq 2 in ref 9); the amplitude of the activity change increases with (but is not merely proportional to) the amount of inhibitor injected.

whereas recovery of activity is limited by $\mathrm{CO}$ release from the enzyme (typical time constant $\sim 1 \mathrm{~min}$ ). ${ }^{7 \mathrm{a}, 7 \mathrm{~b}}$ Correction for the effect of film desorption is described in SI section III. ${ }^{8}$ Inhibition by $\mathrm{CO}$ is fully reversible at $-0.16 \mathrm{~V}$ (Figure 1C) and only partly reversible at -0.36 and $-0.47 \mathrm{~V}$ (Figure 1D,E). Experiments with the enzyme from $\mathrm{Cr}$ gave similar results (SI, Figure S2).

We fitted the chronoamperometric data (dashed lines in Figure 1) using the kinetic model we introduced before for interpreting oxygen inhibition. ${ }^{6,7 \mathrm{a}, 7 \mathrm{~b}}$ As depicted in Figure 2, this model assumes that the formation of an inactive $\mathrm{CO}$ adduct (second-order rate constant $k_{\text {in }}$ ) is followed by either CO release (rate $k_{\text {out }}$ ) or irreversible inactivation (rate $k_{3}$ ). This is supported by the finding from independent crystallographic and spectroscopic investigations that exogenous $\mathrm{CO}$ binds at a single position on the $2 \mathrm{Fe}$ subsite. ${ }^{10}$ Figure 2 shows the dependence on electrode potential of the rate constants determined by fitting data such as those in Figure $1 \mathrm{C}-\mathrm{E}$. The values of the "in" and "out" rates are consistent with those determined in early experiments carried out with the enzyme from $C p$ without precise potential control. ${ }^{11} k_{\text {out }}$ is constant over a large range of electrode potential, whereas $k_{\text {in }}$ decreases and $k_{3}$ increases in the potential range where we expect Hred to be the dominant species in the steady state. Indeed, the change in $k_{\text {in }}$ is well described by an $n=1$ sigmoid centered on $E=-0.33 \mathrm{~V}$ (black line in Figure 2A), close to the equilibrium potential of the Hox/Hred couple $\left(-0.4 \mathrm{~V}\right.$ at $\mathrm{pH} 8$ in $\left.\mathrm{Cr}^{2}\right)$. This suggests that Hred is the species that reacts irreversibly with $\mathrm{CO}$.

The loss of activity after prolonged exposure to $\mathrm{CO}$ at $-0.47 \mathrm{~V}$ is irreversible: it cannot be recovered by removing $\mathrm{CO}$ from the solution and poising the electrode at either very low or high potential, e.g., at $-0.76 \mathrm{~V}$ for $60 \mathrm{~s}$ (SI Figure S3, panels E, F) or at -0.76 or $-0.16 \mathrm{~V}$ for $10 \mathrm{~min}$ (not shown). However, Figure S3
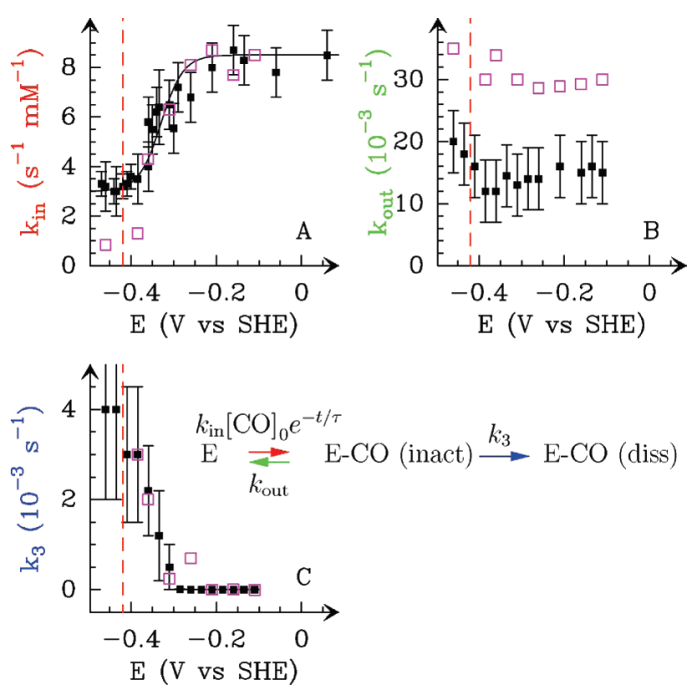

Figure 2. $\mathrm{CO}$ inhibition kinetic parameters obtained by fitting data obtained with $\mathrm{Ca}$ (black) and $\mathrm{Cr}$ (purple) $\mathrm{H}_{2}$ ases ( 1 atm of $\mathrm{H}_{2}, \mathrm{pH} 7$, $30^{\circ} \mathrm{C}$ ). The values of $k_{\text {in }}$ obtained with $\mathrm{Cr}$ have been divided by 10 . The vertical dashed line marks the OCP.

\section{Scheme 2. General Structure of Models 1-6 Used To Study Reaction with $\mathrm{CO}^{a}$}

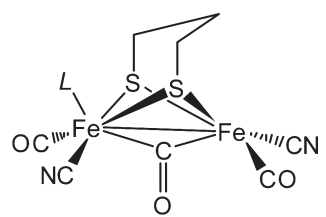

${ }^{a}$ The models formally correspond to the $\mathrm{Fe}^{\mathrm{II}} \mathrm{Fe}^{\mathrm{I}}(\mathbf{1}-3)$ or $\mathrm{Fe}^{\mathrm{I}} \mathrm{Fe}^{\mathrm{I}}(4-6)$ redox states of the dinuclear cluster. See text for the nature of $\mathrm{L}$. The formal valences of the cubane irons are $2 \mathrm{Fe}^{\mathrm{II}} 2 \mathrm{Fe}^{\mathrm{III}}$. Some properties of models 1, 3, 4, and 6 have been discussed in ref 12 .

also demonstrates that the $\mathrm{H}$-cluster can be rescued in extremis if the electrode potential is taken to a very low value (below $-0.6 \mathrm{~V}$, where Hsred should be the dominant species) before the irreversible reaction has time to proceed (Figure S3, panels C, D); in this nonphysiological range of potential, the data could not be accurately analyzed (SI Figure S5), possibly because of an additional inactivation process.

The molecular origin of the observed behaviors is revealed by the results of DFT calculations carried out on models of the Hox, Hred, and Hsred forms of the active site (see SI for details on models and calculations). We first examine $\mathrm{CO}$ binding to a series of $\mathrm{Fe}^{\mathrm{II}} \mathrm{Fe}^{\mathrm{I}}$ and $\mathrm{Fe}^{\mathrm{I}} \mathrm{Fe}^{\mathrm{I}}$ models of the H-cluster (Scheme 2 and SI Table S1) characterized by the general structure $[(\mu$-pdt $)$ $\left.\mathrm{Fe}_{2}(\mathrm{CO})_{3}(\mathrm{CN})_{2}(\mathrm{~L})\right]$, where pdt $=$ propanedithiolate and $\mathrm{L}=\mathrm{CH}_{3} \mathrm{~S}^{-}$(models 1 and 4), $\mathrm{CH}_{3} \mathrm{SH}$ (2 and 5), or $\left[\mathrm{Fe}_{4} \mathrm{~S}_{4^{-}}\right.$ $\left.\left(\mathrm{CH}_{3} \mathrm{~S}\right)_{4}\right]^{2-}(3$ and 6$)$.

The most relevant DFT results are as follows: (i) $\Delta G^{0}$ values for $\mathrm{CO}$ binding to $\mathrm{Fe}^{\mathrm{II}} \mathrm{Fe}^{\mathrm{I}}$ models (from -6.4 to $-10.8 \mathrm{kcal}$ ) mol) match remarkably well the experimental value for $\mathrm{CO}$ binding to Hox: $-8 \mathrm{kcal} / \mathrm{mol}$ for $\mathrm{Ca}$ FeFe hydrogenase, deduced from the ratio $k_{\text {out }} / k_{\text {in }}=1.8 \mu \mathrm{M}$ at high potential in Figure $2 \mathrm{~A}, \mathrm{~B}$; $-9 \mathrm{kcal} / \mathrm{mol}$ for the enzyme from $\mathrm{C} r$, deduced from $k_{\text {out }} / k_{\text {in }}=$ $0.4 \mu \mathrm{M}$. (ii) $\mathrm{CO}$ binds more strongly to the $\mathrm{Fe}^{\mathrm{II}} \mathrm{Fe}^{\mathrm{I}}$ model 1 than to the corresponding $\mathrm{Fe}^{\mathrm{I}} \mathrm{Fe}^{\mathrm{I}}$ model 4 , but (iii) the reaction of $\mathrm{CO}$ with Hred models 5 and 6 leads to irreversible cleavage (see 
SI sections VIII and IX) of the bond between the proximal Fe atom of the diiron subcluster and the $S$ atom (referred to as $S_{\text {cys }}$ in the following) of the L ligand (Scheme 3). In particular, upon binding of the exogenous $\mathrm{CO}$ ligand to Hred models, in which the iron atoms already fulfill the 18-electron rule, at least one bond must be cleaved. Since $\mathrm{CO}$ is a better ligand to $\mathrm{Fe}(\mathrm{I})$ than $\mathrm{CH}_{3}$ $\mathrm{SH}, \mathrm{Fe}-\mathrm{S}\left(\mathrm{CH}_{3}\right)$ bond breaking occurs. Our calculations show

Scheme 3. Cleavage of the $\mathrm{Fe}-\mathrm{S}_{\text {cys }}$ Bond Observed upon $\mathrm{CO}$ Binding to Models 5 and 6
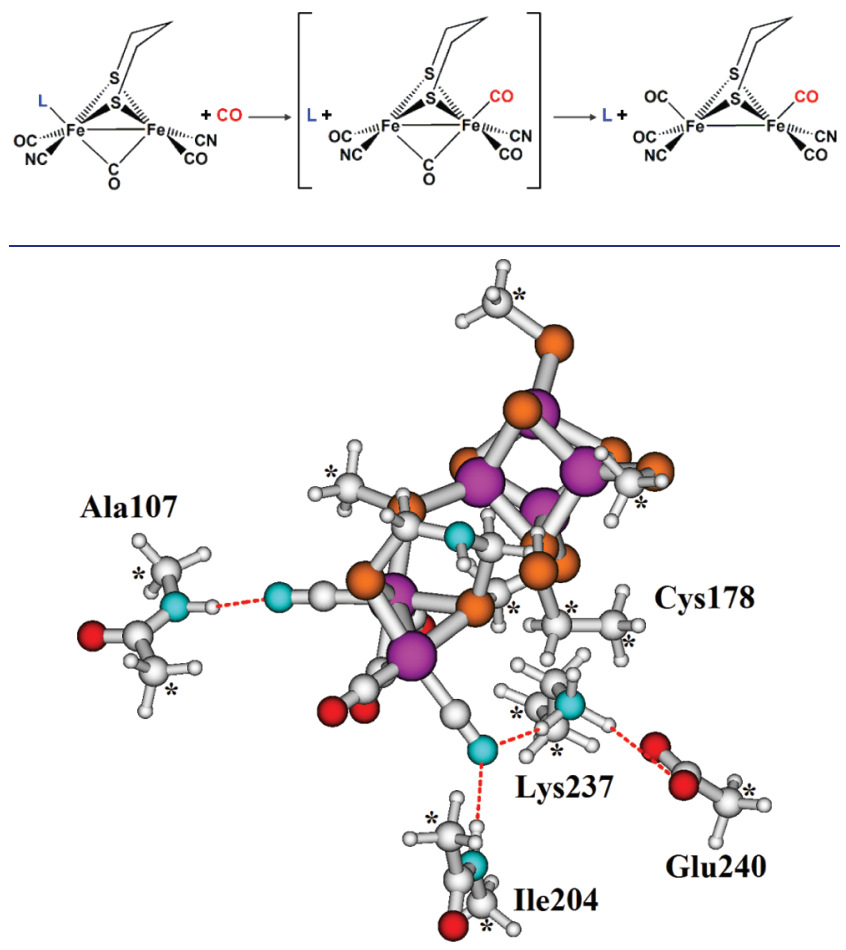

Figure 3. QM structure of the extended Hox model 7. The carbon atoms marked with an asterisk were kept fixed at the crystallographic position during calculations to avoid unrealistic conformational rearrangements. QM models 7-9 differ in the formal redox state of the Fe ions: 7, $\mathrm{Fe}^{\mathrm{II}} \mathrm{Fe}^{\mathrm{I}}-2 \mathrm{Fe}^{\mathrm{III}} 2 \mathrm{Fe}^{\mathrm{II}}$ (i.e., $\left.\mathrm{H}_{\text {ox }}\right) ; 8, \mathrm{Fe}^{\mathrm{I}} \mathrm{Fe}^{\mathrm{I}}-2 \mathrm{Fe}^{\mathrm{III}} 2 \mathrm{Fe}^{\mathrm{II}}\left(\mathrm{H}_{\text {red }}\right) ; 9, \mathrm{Fe}^{\mathrm{I}} \mathrm{Fe}^{\mathrm{I}}-$ $\mathrm{Fe}^{\mathrm{III}} 3 \mathrm{Fe}^{\mathrm{II}}\left(\mathrm{H}_{\text {sred }}\right)$. that, upon $\mathrm{CO}$ binding to model 5, a molecular orbital with antibonding character with respect to the $\mathrm{Fe}-\mathrm{S}\left(\mathrm{CH}_{3}\right)$ bond and to the $\mathrm{Fe}-\mathrm{CO}$ bond in the apical position becomes doubly occupied (see SI section VIII and Figure S6). Very similar results were obtained when the pdt chelating ligand was replaced with dtma (data not shown).

The behavior of Hred models 5 and $\mathbf{6}$ upon reaction with $\mathrm{CO}$ helps to understand why inactivation of Hred by $\mathrm{CO}$ is irreversible. In fact, rupture of $\mathbf{5}$ and $\mathbf{6}$ upon $\mathrm{CO}$ binding initially gives the fully saturated $\left[(\mu \text {-pdt }) \mathrm{Fe}_{2}(\mu-\mathrm{CO})(\mathrm{CO})_{3}(\mathrm{CN})_{2}\right]^{2-}$ compound, which would rearrange (if unconstrained by the environment) to an inert species featuring only terminal CO ligands (Scheme 3), corresponding to one of the first reported synthetic models of the diiron subcluster of FeFe-hydrogenase. ${ }^{13}$ Our calculations show also that $\mathrm{CO}$ release from $\left[(\mu\right.$-pdt $) \mathrm{Fe}_{2}(\mathrm{CO})_{4^{-}}$ $\left.(\mathrm{CN})_{2}\right]^{2-}$ is thermodynamically very difficult $\left(\Delta E_{\text {dissociation }}=\right.$ $39.7 \mathrm{kcal} / \mathrm{mol}$ ), as expected, and its oxidation is more difficult than that of the parent species $\mathbf{5}$ (SI section X).

To determine whether $\mathrm{Fe}-\mathrm{S}_{\text {cys }}$ bond cleavage is triggered by $\mathrm{CO}$ binding also when the active site is embedded in the protein environment, we have extended the DFT investigation to larger models of the Hox (7) and Hred (8) forms of the active site, which include the entire $\mathrm{H}$-cluster and the amino acids interacting with the diiron unit of the cofactor (Figure 3; see also SI section XI and Table S1). ${ }^{14}$

It turned out that the reaction between the model of Hox (7) and $\mathrm{CO}$ is very exothermic $(\Delta E=-23.8 \mathrm{kcal} / \mathrm{mol})^{15}$ and leads to only a slight elongation of the $\mathrm{Fe}-\mathrm{S}_{\text {cys }}$ bond $(+0.16 \AA$, Table $S 1)$. On the other hand, the reaction between $\mathrm{CO}$ and the Hred model $8(\Delta E=-17.3 \mathrm{kcal} / \mathrm{mol})$ is accompanied by an $\mathrm{Fe}-\mathrm{S}_{\text {cys }}$ distance elongation greater than $0.5 \AA$, indicating cleavage of the $\mathrm{Fe}-\mathrm{S}_{\text {cys }}$ bond.

To understand the release of $\mathrm{CO}$ and the rescue of activity that are observed when the electrode potential is stepped to a very low value just after CO binding (SI Figure S3, panel C), we have also studied CO binding to a large DFT model of the Hsred redox state (9), which was obtained by monoelectron reduction of $\mathbf{8}$. We found that reaction between 9 and $\mathrm{CO}$ is even less exothermic than in the case of the corresponding Hred model $(-15 \mathrm{kcal} / \mathrm{mol})$, suggesting low affinity of Hsred for CO. In addition, the $\mathrm{Fe}-\mathrm{S}_{\mathrm{cys}}$ bond in $\mathbf{9}$, even if significantly elongated

Scheme 4. Schematic Representation of the Reactivity of the H-Cluster with $\mathrm{CO}^{a}$

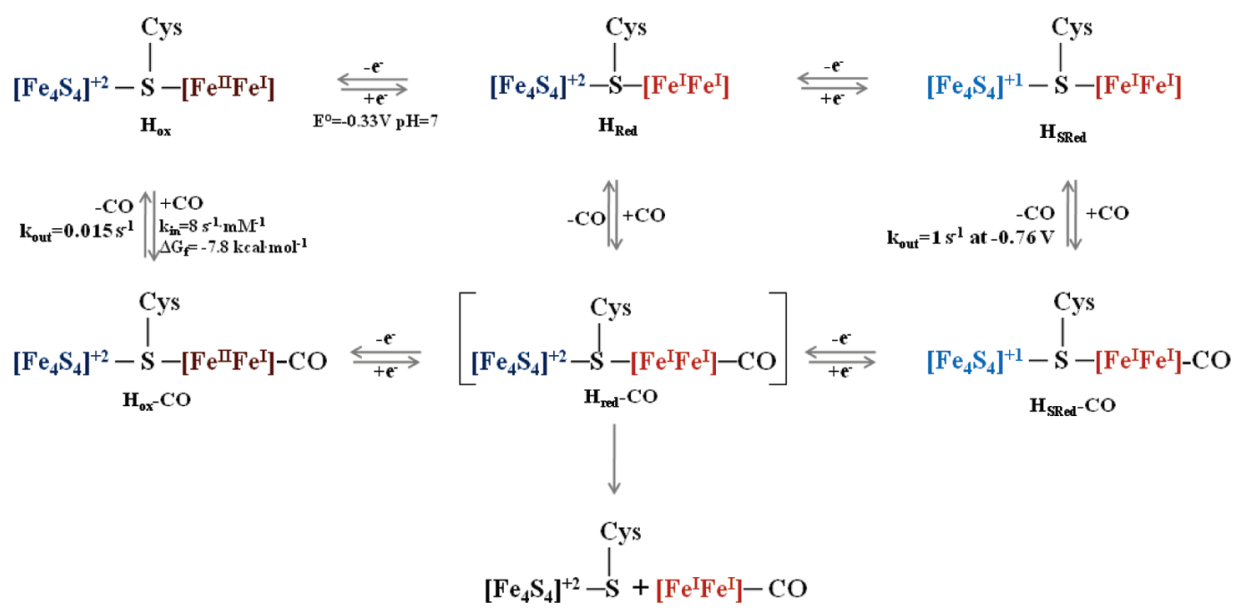

${ }^{a}$ The value of $k_{\text {out }}=1 \mathrm{~s}^{-1}$ for CO dissociation from Hsred-CO is measured in the very low potential experiment shown in SI Figure S3, panel C. 
(+0.3 $\AA$ ), is not cleaved upon CO binding, indicating that in the Hsred state the structural integrity of the $\mathrm{H}$-cluster is maintained.

Scheme 4 summarizes our findings. Most importantly, we conclude that $\mathrm{CO}$ binding to Hred irreversibly inactivates the enzyme by breaking down the $\mathrm{H}$-cluster, giving the inactive, inert compound $\left[(\mu \text {-dtma }) \mathrm{Fe}_{2}(\mathrm{CO})_{4}(\mathrm{CN})_{2}\right]^{2-}$. Although we do not have specific information about the fate of the stable, broken parts of the $\mathrm{H}$ cluster, we consider unlikely that they dissociate from the enzyme, because this would require a major conformation change to open a pathway though the protein matrix (as occurs for $\mathrm{H}$-cluster maturation). ${ }^{16}$ It will be interesting to perform further experiments to trap and spectroscopically characterize the inactivated active site. EPR could be used with the enzyme from $\mathrm{Cr}$ that has no electron-transferring FeS clusters, but the Hsred state will have to be characterized first, ${ }^{2}$ and we have no indication that the dissociated cubane will be paramagnetic. However, it is likely that the $\mathrm{CO}$-induced disruption of the $\mathrm{H}$-cluster should have consequences on the FTIR signature of either enzyme.

It is remarkable that the reaction of $\mathrm{CO}$ binding engages the entire $\mathrm{H}$-cluster, rather than only the $\mathrm{Fe}_{2}$ subsite. This is reminiscent of the recent finding that $\mathrm{O}_{2}$ inhibition involves initial attack of the distal $\mathrm{Fe}$ ion, followed by damage to the cubane. ${ }^{7 \mathrm{a}, 17}$

\section{ASSOCIATED CONTENT}

S Supporting Information. Complete ref 6, experimental and numerical methods, raw data corresponding to Figure 1, electrochemical signals obtained with $\mathrm{Cr} F \mathrm{FeF}$ hydrogenase, results of electrochemical experiments at very low potential, Table S1, description of the possible pathways for the reaction of $\mathrm{Fe}^{\mathrm{I}} \mathrm{Fe}^{\mathrm{I}}$ models with $\mathrm{CO}$, other numerical details, including total energy and optimized atomic coordinates of all models discussed in the paper. This material is available free of charge via the Internet at http://pubs.acs.org.

\section{AUTHOR INFORMATION}

\section{Corresponding Author}

luca.degioia@unimib.it; christophe.leger@ifr88.cnrs-mrs.fr

\section{ACKNOWLEDGMENT}

We thank the ANR for funding, and we acknowledge support from the Pôle de compétitivité Capénergies. K.S. was supported by the European Commission (SolarH2 212508).

\section{REFERENCES}

(1) (a) Silakov, A; Reijerse, E. J.; Albracht, S. P.; Hatchikian, E. C.; Lubitz, W. J. Am. Chem. Soc. 2007, 129, 11447-11458. (b) Tard, C.; Pickett, C. J. Chem. Rev. 2009, 109, 2245-2274. (c) Gloaguen, F.; Rauchfuss, T. B. Chem. Soc. Rev. 2009, 38, 100-108.

(2) Silakov, A.; Kamp, C.; Reijerse, E.; Happe, T.; Lubitz, W. Biochemistry 2009, 48, 7780-7786.

(3) Adams, M. W. J. Biol. Chem. 1987, 262, 15054-15061.

(4) Goldet, G.; Brandmayr, C.; Stripp, S. T.; Happe, T.; Cavazza, C.; Fontecilla-Camps, J. C.; Armstrong, F. A. J. Am. Chem. Soc. 2009, 131, 14979-14989.

(5) (a) Léger, C.; Bertrand, P. Chem. Rev. 2008, 108, 2379-2438. (b) Vincent, K. A.; Parkin, A.; Armstrong, F. A. Chem. Rev. 2007, 107, 43664413.

(6) Liebgott, P.-P.; et al. Nat. Chem. Biol. 2010, 6, 63-70.

(7) (a) Baffert, C.; Demuez, M.; Cournac, L.; Burlat, B.; Guigliarelli, B.; Bertrand, P.; Girbal, L.; Léger, C. Angew. Chem., Int. Ed. 2008, 47,
2052-2054. (b) Lautier, T.; Ezanno, P.; Baffert, C.; Fourmond, V.; Cournac, L.; Fontecilla-Camps, J. C.; Soucaille, P.; Bertrand, P.; Meynial-Salles, I.; Léger, C. Faraday Discuss. 2011, 148, 385-407. (c) Sybirna, K.; Antoine, T.; Lindberg, P.; Fourmond, V.; Rousset, M.; Méjean, V.; Bottin, H. BMC Biotechnol. 2008, 8, 73.

(8) Fourmond, V.; Lautier, T.; Baffert, C.; Leroux, F.; Liebgott, P. P.; Dementin, S.; Rousset, M.; Arnoux, P.; Pignol, D.; Meynial-Salles, I.; Soucaille, P.; Bertrand, P.; Léger, C. Anal. Chem. 2009, 81, 2962-2968.

(9) Almeida, M. G.; Silveira, C. M.; Guigliarelli, B.; Bertrand, P.; Moura, J. J. G.; Moura, I.; Léger, C. FEBS Lett. 2007, 581, 284-288.

(10) (a) Lemon, B. J.; Peters, J. W. Biochemistry 1999, 38, 1296912973. (b) Bennet, B.; Lemon, B. J.; Peters, J. W. Biochemistry 2000, 39, 7455-7460. (c) Telser, J.; Benecky, M. J.; Adams, M. W.; Mortenson, L. E.; Hoffman, B. M. J. Biol. Chem. 1986, 261, 1353613541. (d) Stripp, S.; Sanganas, O.; Happe, T.; Haumann, M. Biochemistry 2009, 48, 5042-5049.

(11) Thauer, R. K.; Käufer, B.; Zähringer, M.; Jungermann, K. Eur. J. Biochem. 1974, 42, 447-452.

(12) Bertini, L.; Greco, C.; Bruschi, M.; Fantucci, P.; De Gioia, L. Organometallics 2010, 29, 2013-2025.

(13) (a) Le Cloirec, A.; Best, S. P.; Borg, S.; Davies, S. C.; Evans, D. J.; Hughes, D. L.; Pickett, C. J. Chem. Commun. 1999, 2285-2286. (b) Lyon, E. J.; Georgakaki, I. P.; Reibenspies, J. H.; Darensbourg, M. Y. Angew. Chem., Int. Ed. 1999, 38, 3178-3180. (c) Schmidt, M.; Contakes, S. M.; Rauchfuss, T. B. J. Am. Chem. Soc. 1999, 121, 9736-9737.

(14) Bruschi, M.; Greco, C.; Kaukonen, M.; Fantucci, P.; Ryde, U.; De Gioia, L. Angew. Chem., Int. Ed. 2009, 48, 3503-3506.

(15) Free energy values were not computed for reactions of models 7-9, due to the too high computational cost that would be necessary to evaluate the entropic contribution to $\Delta G$ for such large QM models.

(16) Mulder, D. W.; Boyd, E. S.; Sarma, R.; Lange, R. K.; Endrizzi, J. A.; Broderick, J. B.; Peters, J. W. Nature 2010, 465, 248-251.

(17) (a) Stripp, S. T.; Goldet, G.; Brandmayr, C.; Sanganas, O.; Vincent, K. A.; Haumann, M.; Armstrong, F. A.; Happe, T. Proc. Natl. Acad. Sci. U.S.A. 2009, 106, 17331-17336. (b) Stiebritz, M. T.; Reiher, M. Inorg. Chem. 2009, 48, 7127-7140. 